\title{
Zastosowanie metody kowariancji do określenia ryzyka na rynku nieruchomości komercyjnych
}

\section{Wstęp}

Ryzyko, jego istota oraz pomiar są podstawowymi pojecciami i wyzwaniami teorii nowoczesnych finansów, a w szczególności analiz szeroko pojętych inwestycji. Zdefiniowanie ryzyka $w$ sposób jednoznaczny i precyzyjny jest zadaniem niezwykle trudnym, gdyż ryzyko charakteryzuje aspekt obiektywny, wynikający $\mathrm{z}$ niepewności na rynku, oraz aspekt subiektywny, wynikający ze stosunku inwestora do ryzyka ${ }^{1}$. Inaczej będą postrzegać ryzyko drobni inwestorzy - uczestnicy głównie rynku finansowego, inaczej przedstawiciele sektora bankowego czy ubezpieczeniowego działający na rynku kapitałowym, pieniężnym i rynku nieruchomości, a jeszcze inaczej podmioty prawne prowadzące działalność wytwórczą. Można jednak wyróżnić pewne wspólne cechy podejścia do ryzyka charakterystyczne dla wszystkich podmiotów rynku:

- $\quad \mathrm{z}$ reguły ryzyko traktowane jest jako zagrożenie, a więc niebezpieczeństwo poniesienia szkody lub straty, i głównie w takich kategoriach jest analizowane i kwantyfikowane,

- ryzyko jest związane z czynnością dokonana, a więc jest „skutkiem” decyzji i podjętych w jej wyniku działań,

- działania podmiotów skupiają się na minimalizowaniu poziomu ryzyka, a więc takim zarządzaniu ryzykiem, które ma na celu poprawę wyników finansowych lub uzyskanie oczekiwanego, założonego dochodu.

Odnosząc tak postrzegane ryzyko do projektów inwestycyjnych, można powiedzieć, że ryzyko oznacza prawdopodobieństwo, że dochód rzeczywisty (faktyczny) $\mathrm{z}$ inwestycji będzie się różnić od dochodu oczekiwanego ${ }^{2}$. Jedno-

\footnotetext{
${ }^{1} \mathrm{~K}$. Jajuga, T. Jajuga, Inwestycje. Wydawnictwo Naukowe PWN, Warszawa 2002, Wstęp, s. 8. ${ }^{2}$ E.F. Brigham, L.C. Gapenski, Zarzqdzanie finansami. Polskie Wydawnictwo Ekonomiczne. Rozdział II, s. 66.
} 
cześnie dla projektów inwestycyjnych główne wagi ryzyka przypisane będą aspektom planistycznym i decyzyjnym ${ }^{3}$.

Celem prezentowanego opracowania jest próba zastosowania modelu VaR - wartości narażonej na ryzyko do określenia skawantyfikowanego ryzyka wyłącznego przedsięwzięcia inwestycyjnego scharakteryzowanego podstawowymi wskaźnikami rachunku efektywności NPV i IRR.

W opracowaniu zaadaptowano i wdrożono model ryzyka VaR oparty na metodzie kowariancji, wykorzystywanej dotychczas w zarządzaniu ryzykiem aktywami podmiotów rynku finansowego, głównie portfeli inwestycyjnych. Wykorzystanie VaR na płaszczyźnie analiz opłacalności przedsięwzięć inwestycyjnych rzeczowych, segmentu rynku nieruchomości jest działaniem mało rozpoznanym, obarczonym ograniczonym zaufaniem ze względu na odmienny charakter instrumentów rynku finansowego i inwestycji rzeczowych. Prezentowana analiza ryzyka obejmuje głównie aspekty związane z procesem decyzyjnym kredytodawcy, dla którego fundamentalne znaczenie ma wiarygodność spełnienia warunków umowy w okresie kredytowania oraz poziom zabezpieczenia wierzytelności.

\section{Metoda kowariancji}

Metoda kowariancji jest najpopularniejszym sposobem kalkulacji wartości narażonej na ryzyko VaR. Określenie potencjalnej straty na danym portfelu przy wykorzystaniu metody kowariancji wymaga oszacowania wskaźnika zmienności dla poszczególnych instrumentów tworzących portfel oraz wartości pozycji.

Kowariancja dla pojedynczej pozycji liczona jest następującą zależnością:

$$
\operatorname{VaR}_{t}=\left[1-e^{-1,65_{(t-1)}}\right] \times V_{t-1} \times \sqrt{t}
$$

gdzie: $\sigma$-odchylenie standardowe,

$V_{t}$ - wartość aktywów w dniu $t$,

$t$ - horyzont czasowy.

\footnotetext{
${ }^{3}$ W. Rogowski, M. Kąkol, Zarzqdzanie ryzykiem banku przy inwestycjach mieszkaniowych z uwzględnieniem wplywu ryzyka kredytowego nabywców mieszkań. Uwarunkowania i kierunki rozwoju modelowania ryzyka kredytowego wierzytelności hipotecznych. Związek Banków Polskich, Warszawa 2003, s. 81.

${ }^{4}$ Money.pl 06.08.2003 r.
} 
lub formułą uproszczoną:

$V a R=V \times P$

gdzie: $V$-zmienność,

$P$-wartość pozycji.

Uwzględniając 95-procentowy poziom ufności uzyskiwany przy przemnożeniu odchylenia standardowego przez 1,65 (dla zmienności liczonej jednym odchyleniem standardowym), powyższy wzór przybiera postać:

$$
V a R=1,65 \times V \times P
$$

Dla portfela składającego się z wielu instrumentów model VaR liczony za pomocą kowariancji ma postaćs:

$$
V a R_{p}=\sqrt{\sum \rho_{i}^{2} \times \sigma_{i}^{2}+\sum_{i}} \sum_{j} \rho_{i} \times \rho_{j} \times \sigma_{i} \times \rho_{i j}
$$

gdzie: $\rho_{i}, \rho_{j}-$ udział instrumentów $i, j$ w portfelu,

$\sigma_{i}, \sigma_{j}-$ wskaźniki zmienności instrumentów $i, j$,

$\rho_{i j}$-współczynnik korelacji między instrumentami $i, j$.

W praktyce, $V a R$ dla portfela liczona jest na podstawie następującej zależności: ${ }^{6}$

$$
V a R=\sqrt{V \times C \times V^{T}}
$$

gdzie: $V$-wektor wierszowy wartości $V a R$ dla każdej indywidualnej pozycji,

$C$ - macierz korelacji,

$V^{T}$ - macierz transponowana $V$.

\section{Charakterystyka rynku nieruchomości w segmencie wynajmu powierzchni biurowych - identyfikacja potencjalnych czynników ryzyka}

Kryzys polskiej gospodarki obserwowany w ciagu ostatnich dwóch lat w szczególności dotknął sektor budowlany, w tym rynek nieruchomości biurowych. Kłopoty finansowe firm i spółek oraz znaczne ograniczenie kosztownych

\footnotetext{
${ }^{5}$ P. Best, Wartość narażona na ryzyko. Dom Wydawniczy ABC, Kraków 2000, Rozdział 2, s. 36. ${ }^{6}$ P. Best, Wartość narażona na ryzyko. Dom Wydawniczy ABC, Kraków 2000, Rozdział 2, s. 37.
} 


\section{0}

inwestycji rzeczowych spowodowały znaczace zmniejszenie popytu na powierzchnie komercyjne, przy wciąż wzrastającej podaży.

Pod koniec 2002 r. nowoczesne powierzchnie biurowe w Warszawie osiagnęły poziom $1787565 \mathrm{~m}^{2}$, co stanowiło wzrost o $11 \%$ w stosunku do $2001 \mathrm{r}$. W 2002 r. oddano do użytku sześć budynków biurowych w centralnym obszarze biznesu i dwadzieścia poza centrum. W pierwszej połowie $2003 \mathrm{r}$. ukończono realizację kolejnych $42000 \mathrm{~m}^{2}$ powierzchni biurowej, z której większość (82\%) jest zlokalizowana $\mathrm{w}$ centrum miasta, natomiast poza centrum znajduje się tylko $7700 \mathrm{~m}^{2}$. Wzrost ilości i jakości powierzchni oferowanych poza centrum oraz niższe stawki czynszów sprzyjały znacznemu zainteresowaniu najemców tą lokalizacją, co powodowało, że $77 \%$ całości wynajętej powierzchni w 2002 r. zlokalizowane było poza centrum Warszawy. W 2003 r. szacowano ilość nowoczesnej powierzchni biurowej w Warszawie na ok. $1,81 \mathrm{mln}^{2}$. Do głównych lokalizacji należą kolejno: City Center, Kasprzaka (Wola), Aleje Jerozolimskie (Włochy), Żwirki i Wigury (Okęcie), Domaniewska, Marynarska, Wołoska (Mokotów), Puławska (Ursynów).

Aktualnie przeciętne stawki czynszu za powierzchnie biurowe zlokalizowane poza centrum ksztaltują się na poziomie 14-17 USD za $\mathrm{m}^{2}$ i miesiąc, i oczekuje się dalszego wzrostu zawieranych umów najmu wywołanego spadkiem czynszów oraz dodatkowymi udogodnieniami oferowanymi najemcom.

Stawki czynszu zà powierzchnie biurowe najwyższej jakości i w najlepszych lokalizacjach utrzymują się na poziomie 23-25 USD za $\mathrm{m}^{2}$ i miesiąc, i przewiduje się, że pozostaną na tym poziomie przez najbliższe 12 miesięcy. Przeciętna wysokość stawki płaconej przez najemców powierzchni biurowych $\mathrm{w}$ centrum oscyluje $\mathrm{w}$ przedziale 19-22 USD za m² i miesiąc.

Ogólny wskaźnik powierzchni biurowej niewynajętej w Warszawie wynosi ok. $16,1 \%$. Analizy wskazują na spadkowy trend pustostanów poza centrum z 18,3 do 14,9\% - spowodowany głównie mniejszą aktywnością deweloperską. Wskaźnik powierzchni niewynajętej w centrum miasta kształtuje się na poziomie $17,4 \%$ i jest wynikiem oddania do użytku nowych powierzchni oraz zwiększonej ilości powierzchni wtórnych na rynku. W najbliższych latach przewidywane jest stopniowe obniżenie wskaźnika pustostanów oraz ożywienie popytu na powierzchnie biurowe, głównie będące następstwem spadku ilości nowych inwestycji, ograniczenia podaży oraz wzrostu popytu wywołanego ożywieniem gospodarczym i wstapieniem Polski do Unii Europejskiej. Najczęściej umowy najmu zawierane są na okres 3-5 lat, a przeciętne okresy bezczynszowe wynoszą 3-9 miesięcy.

${ }^{7}$ muratorplus.pl. 12.12.2003 r. 
W pierwszej połowie 2003 r. zaobserwowano w Warszawie nienotowany dotychczas poziom zainteresowania rynkiem inwestycyjnym, kreowany głównie przez przedstawicieli niemieckich otwartych funduszy inwestycyjnych. Odzwierciedleniem podejmowanych inwestycji na rynku nieruchomości biurowych było zawarcie w pierwszym półroczu 2003 r. m.in. trzech znaczących transakcji:

- Brama Zachodnia (West GATT) - budynek biurowy o powierzchni 23000 $\mathrm{m}^{2}$ został sprzedany za $61,5 \mathrm{mln}$ euro, przy nieujawnionej stopie kapitalizacji,

- Jerozolimskie Business Park D - obiekt biurowy o powierzchni $8000 \mathrm{~m}^{2}$ został zakupiony przy stopie kapitalizacji $11,20 \%$,

- Bitwy Warszawskiej Business Centre - kompleks obejmujący $20000 \mathrm{~m}^{2}$ powierzchni biurowej został sprzedany przez dewelopera za kwotę przekraczającą 57 mln euro, przy nieujawnionej stopie kapitalizacji.

W 2003 r. polski rynek inwestycyjny osiągnął pozycję preferowaną przez międzynarodowych inwestorów. Znaczący wzrost zainteresowania był wynikiem m.in. pozytywnego wyniku referendum popierającego przystapienie do Unii Europejskiej, stabilizacją ekonomiczną oraz dalszymi przewidywaniami co do obniżania stóp procentowych.

Szacowane stopy kapitalizacji dla najlepszych nieruchomości tego segmentu osiągają poziom ok. 9\%. Średnie stopy kapitalizacji dla najlepszych obiektów biurowych w Warszawie oscylują w przedziale 9,5-10\%.

Spośród czynników ograniczających napływ kapitału inwestycyjnego należy wymienić brak dobrych instytucjonalnych produktów inwestycyjnych z długoterminowymi umowami najmu oraz odpowiednimi stawkami czynszowymi. Potencjalni inwestorzy zainteresowani nieruchomościami komercyjnymi, obserwując $w$ ostatnich latach spadek stawek czynszowych w obiektach biurowych, rozważają alternatywne segmenty rynku nieruchomości, a więc powierzchnie handlowe, handlowo-magazynowe czy logistyczne. Ryzyko postrzegane przez inwestora jest więc głównie ryzykiem operacyjnym, związanym $\mathrm{z}$ niepewnością co do rzeczywistej wysokości spodziewanych dochodów $\mathrm{z}$ inwestycji. Ryzyko operacyjne jest typowym rodzajem ryzyka, które charakteryzuje nieruchomości przeznaczone na wynajem na podstawie umów zawartych na czas nieoznaczony lub nieruchomości, których sposób użytkowania jest ściśle związany z działalnością wykonywaną przez przedsiębiorcę.

Ryzyko operacyjne to również główny czynnik wpływający na poziom podstawowego miernika opłacalności inwestycji - wymaganej stopy zwrotu.

${ }^{8}$ muratorplus.pl. 12.12.2003 r. 
Ryzyko nieosiagnięcia przez inwestora oczekiwanej stopy kapitalizacji wynika bezpośrednio z:

- niższych niż założono staiwek czynszu odniesionych do $1 \mathrm{~m}^{2}$ powierzchni użytkowej,

- poziomu pustostanów - udziału powierzchni wynajętej do potencjalnej powierzchni przeznaczonej na wynajem,

- niedotrzymania warunków umowy przez wynajmującego.

- niepewnego kursu walutowego, w przypadku umów najmu zawartych w walucie obcej.

Oczywiście każdy projekt inwestycyjny oprócz ryzyka operacyjnego narażony jest na ryzyko związane $z$ otoczeniem, w którym funkcjonuje, a więc ryzyko prawne, polityczne, stopy procentowej czy inflacji. Można jednak przyjąć, że czynniki te są dobrze identyfikowane i uwzględniane przez uczestników rynku, czego odzwierciedleniem jest określona w danych warunkach wielkość popytu i podaży, regulująca odpowiednio poziom stawek czynszów oraz pustostanów.

\section{Analiza finansowa}

\section{Założenia analizy}

Specyfika analizy opłacalności przedmiotowego projektu inwestycyjnego rozpatrywana przez pryzmat kwantyfikowanego ryzyka osiagnięcia określonego poziomu wskaźnika opłacalności NPV wymaga wprowadzenia dodatkowych założeń, które odbiegają od klasycznego ujęcia rachunku efektywności.

\section{Okres analizy}

W ekonomicznych analizach opłacalności projektów inwestycyjnych okres prognozy obejmuje zazwyczaj czas ekonomicznego życia projektu inwestycyjnego, na który składają się faza przedinwestycyjna, faza realizacji, faza operacyjna i faza likwidacji. Okres ekonomicznego życia projektu może być ograniczony przesłankami technicznymi, funkcjonalnymi lub prawnymi. W przypad$\mathrm{ku}$ projektów inwestycyjnych dotyczących nieruchomości okres życia ekonomicznego jest stosunkowo długi i z reguły ograniczany przesłankami zużycia technicznego lub funkcjonalnego obiektu kubaturowego. Najczęściej w praktyce okres predykcji finansowej złożony jest z dwóch części - analizy szczegółowej, obejmującej w zależności od celu opracowania 5-10 lat, oraz pozostałego okresu prognozy, wyrażanego zazwyczaj poprzez skapitalizowaną wartość rezydualną. $Z$ punktu widzenia instytucji współfinansujących inwestycję za- 
chowanie się przedsięwzięcia $\mathrm{w}$ takim okresie ma znaczenie fundamentalne $i$ jest czynnikiem deterministycznym w procesie decyzyjnym. Przyjmując więc założenie, że głównym zainteresowanym poziomem podejmowanego ryzyka jest kredytodawca, okres analizy na potrzeby zastosowanià modelu VaR ograniczono do 11 lat, w których następuje budowa trwająca 2 lata (2004-2005) i operacyjne funkcjonowanie obiektu oraz spłata kredytu.

W całym okresie analizy obliczenia prowadzone są w ujęciu realnym, nie jest uwzględniona prognoza inflacji.

\section{Stopa dyskonta}

W dynamicznych metodach analizy efektywności inwestycji stopa dyskonta utożsamiana jest z kosztem użycia kapitału. W przypadku projektów finansowanych kapitałem własnym i obcym, stopę dyskonta przyjmuje się jako średnioważony koszt zaangażowania kapitału (WACC). W obliczeniach kosztu zaangażowania środków pieniężnych w nieruchomości uzasadnione jest wykorzystanie teorii wyceny nieruchomości, o ile tylko istnieje wystarczająca ilość wiarygodnych danych rynkowych. Na potrzeby rachunku efektywności przedmiotowej inwestycji przyjęto, że stopa dyskonta w kolejnych latach projekcji jest stała, wynosi $9 \%$ i odzwierciedla wymaganą przez inwestorów stope zwrotu, obejmująca premię za podejmowane ryzyko.

\section{Miesięczne stawki czynszu za wynajmowane powierzchnie}

Wysokość miesięcznych stawek czynszu za powierzchnie biurowe, magazynowe i wspólne przyjęto na podstawie analizy rynkowych umów najmu podpisywanych $\mathrm{z}$ właścicielami nieruchomości segmentu biurowego. Umowy zawierane na wynajem powierzchni biurowych klasy A charakteryzują się określeniem dwóch stawek miesięcznego czynszu oraz sprecyzowaniem dodatkowych warunków opłat za wykorzystane media. Cechą charakterystyczną jest podział na wykorzystanie powierzchni biurowych netto oraz udział w powierzchniach wspólnych. Szczegółowe zestawienie przyjętych do obliczeń stawek czynszu przedstawia tabela 1 . W obliczeniach przyjęto założenie stałego poziomu czynszów.

\section{Tabela 1}

Przyjęte do obliczeń stawki czynszu uzyskiwane z wynajmu biurowca

\begin{tabular}{|c|c|c|c|}
\hline $\begin{array}{l}\text { Stawka czynszu } \\
\text { podstawowego, } \\
\text { PLN/1 m² m-c }\end{array}$ & $\begin{array}{c}\text { Stawka czynszu za } \\
\text { pow. wspólne, } \\
\text { PLN } / 1 \mathrm{~m}^{2} \mathrm{~m}-\mathrm{c}\end{array}$ & $\begin{array}{l}\text { Koszt stanowiska } \\
\text { parkingowego, } \\
\text { PLN } / 1 \mathrm{~m}^{2} \mathrm{~m}-\mathrm{c}\end{array}$ & $\begin{array}{l}\text { Opłaty eksploata- } \\
\text { cyjne, PLN/ } 1 \mathrm{~m}^{2} \mathrm{~m}-\mathrm{c}\end{array}$ \\
\hline 100,00 & 40,00 & 600,00 & 15,00 \\
\hline
\end{tabular}

Żódło: Opracowanie własne. 


\section{Pozostałe załoźenia analizy opłacalności}

1. W obliczeniach NPV i IRR pominięto wartość rezydualną oraz likwidacyjną projektu (rys. 1). Istotą prowadzonych badań wykorzystania modelu VaR jest określenie skwantyfikowanego ryzyka inwestycji mierzonego wskaźnikiem opłacalności NPV. Wprowadzenie do obliczeń wartości rezydualnej lub likwidacyjnej, która stanowi znaczący udział w określanym NPV projektu, nie wnosi decydujacych informacji dla procesu decyzyjnego kredytodawcy, a może znacznie zniekształcić wyniki otrzymane w modelu VaR ze względu na bardzo długi horyzont czasowy. Wartość rezydualna lub likwidacyjna będzie miała istotne znaczenie $\mathrm{z}$ punktu widzenia zabezpieczenia ryzyka kredytodawcy, ale wykraczając poza okres spłaty ma znaczenie drugorzędne.

\section{Udział wartości rezydualnej projektu w NPV}

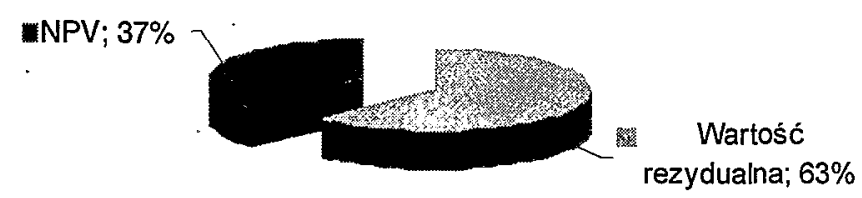

\section{Rysunek 1}

Udział wartości rezydualnej projektu w NPV Źródło: Opracowanie własne.

2. Stawkę podatku dochodowego przyjęto na poziomie $19 \%$.

3. W scenariuszu bazowym przyjęto 85-procentowe wykorzystanie powierzchni biurowych wynikające $z$ umów zawartych na okres 5-letni; w scenariuszu optymistycznym procent wykorzystania lokali biurowych wzrósł do poziomu $95 \%$, co wynika z zawartych umów przedwstępnych.

4. W analizie scenariuszy przyjęto, że głównymi czynnikami determinującymi wskaźniki opłacalności są wpływy osiagane $\mathrm{z}$ najmu powierzchni biurowych uzależnione głównie od wielkości pustostanów oraz nakłady początkowe niezbędne na realizację inwestycji. Przedmiotowy projekt jest mało wrażliwy na koszty operacyjne ze względu na duży udział kosztów stałych niezależnych od poziomu wykorzystania potencjalnej powierzchni.

5. Analiza uwzględnia wszystkie założenia modelu NPV i IRR, a więc założenie o strumieniach uzyskiwanych na koniec każdego roku prognozy. Oznacza to, iż współczynnik dyskonta dla 2004 r. wynosił będzie nie 1 (tak byłoby, gdyby strumienie uzyskiwano na poczattku każdego roku prognozy) tylko 0,91743119 . Założono reinwestowanie strumieni pieniężnych przy wykorzystaniu stopy zwrotu równej stopie dyskonta projektu. 


\section{Obliczenia NPV i IRR dla scenariusza bazowego}

Scenariusz bazowy stanowiący podstawę obliczania wskaźników opłacalności inwestycji został oparty na średnich stawkach wpływów i nakładów określonych na podstawie analizy rynku nieruchomości segmentu biurowego. Dodatkowym argumentem przemawiającym za wiarygodnym poziomem przyjętych danych wyjściowych jest wykorzystanie teorii wyceny bazującej na informacjach z rynku nieruchomości podobnych. W obliczeniach przyjęto wysokość nakładów inwestycyjnych, które w większości wynikały z zawartych umów.

Przeprowadzony rachunek efektywności przedmiotowego projektu w zakresie podstawowych kryteriów decyzyjnych (NPV i IRR) wskazuje, że oba parametry osiągnęły wartości przekraczające wymogi kryterium decyzji pozytywnej:

- wartość zaktualizowana netto NPV $=36955,78$ tys. PLN przy stopie dyskonta $9,0 \%$ - NPV $>0$, projekt należy przyjąć,

- wewnętrzna stopa zwrotu IRR $=26,12 \%, \mathrm{IRR}=26,12 \%>$ stopy dyskonta dla projektu $=9 \%$, projekt należy przyjąć (rys. 2).

\section{IRR przedsięwzięcia inwestycyjnego}

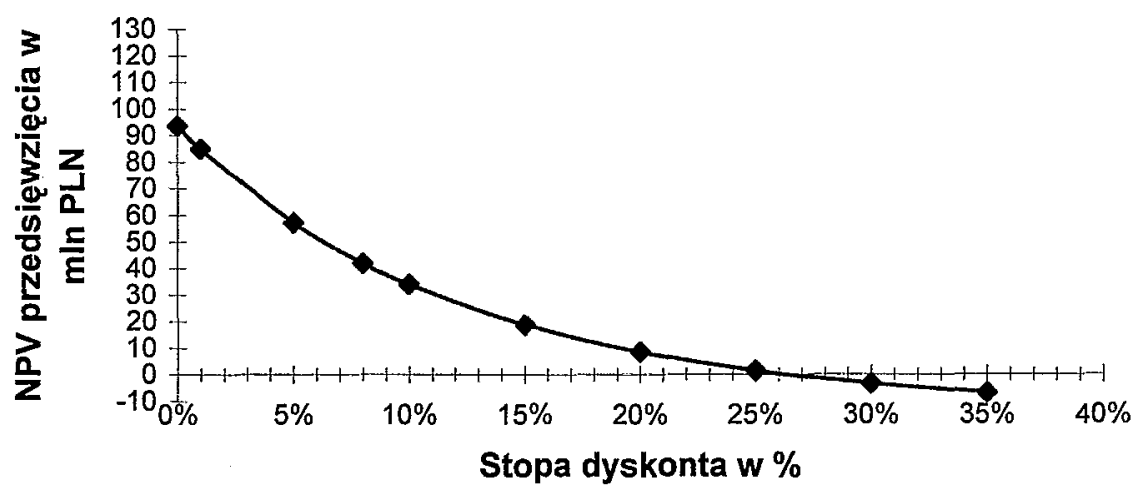

\section{Rysunek 2}

Wewnętrzna stopa zwrotu projektu inwestycyjnego dla wariantu bazowego Żródło: Opracowanie własne.

\section{Analiza wraźliwości projektu inwestycyjnego na wyróżnione rynkowe czynniki ryzyka}

Badania rynku przeprowadzone w zakresie potencjalnych czynników ryzyka wpływających na wysokość dochodów użyskiwanych z działalności operacyjnej obiektów biurowych wskazują, że właściciele nieruchomości ponoszą straty głównie z tytułu udziału powierzchni niewynajętej lub zaległości czyn- 
szowych. Zbyt duża podaż wolnej powierzchni skutkuje obniżaniem stawek za wynajem lub stosowaniem innych upustów, co bezpośrednio wpływa na poziom uzyskiwanych dochodów i niweluje zyski związane ze zwiększeniem udziału powierzchni wynajętych. Uwzględniając wyróżnione czynniki ryzyka inwestycji w nieruchomości komercyjne, dokonano analizy wrażliwości przedmiotowego projektu w następujących wariantach:

- scenariusz optymistyczny - dla sytuacji zawarcia prognozowanych umów najmu zwiększających wykorzystanie powierzchni biurowej do $95 \%$,

- scenariusz umiarkowanie pesymistyczny - dla sytuacji zmniejszenia wpływów o $20 \%$ w stosunku do scenariusza bazowego,

- scenariusz pesymistyczny - dla sytuacji zmniejszenia wpływów o 30\% w stosunku do scenariusza bazowego (tab. 2).

Szczegółowe obliczenia prezentują załączniki na końcu artykułu.

Innym zagrożeniem dla osiąganych wskaźników efektywności inwestycji jest możliwość zmiany nakładów inwestycyjnych. Ryzyko nieosiagnięcia wymaganej stopy zwrotu pojawia się w sytuacji, gdy koszty związane $\mathrm{z}$ realizacja przedsięwzięcia przekraczają zakładane wartości wyjściowe, a biorąc pod uwagę ich wysokość takie niedoszacowanie może w sposób istotny zagrozić powodzeniu podejmowanej inwestycji. Znaczenie trafności oszacowań tych kosztów jest również istotnym czynnikiem podejmowanych decyzji kredytodawcy, dlatego też analizę wrażliwości rozszerzono o następujące warianty dotyczące nakładów inwestycyjnych:

- scenariusz umiarkowanie pesymistyczny - dla sytuacji powiększenia nakładów inwestycyjnych o $20 \% \mathrm{w}$ stosunku do scenariusza bazowego,

- scenariusz pesymistyczny - dla sytuacji powiększenia nakładów inwestycyjnych o $50 \% \mathrm{w}$ stosunku do scenariusza bazowego.

W analizie nie uwzględniono sytuacji zmniejszenia kosztów inwestycji, gdyż byłoby to czynnikiem pozytywnym zwiększającym "margines bezpieczeństwa" zarówno oczekiwań inwestora, jak i ryzyko instytucji wspólfinansującej projekt.

\section{Zmiana wpływów w zależności od stopnia wykorzystania powierzchni obiektu}

\section{Tabela 2}

Zestawienie uzyskanych wyników wskaźników efektywności NPV i IRR dla czterech scenariuszy rynkowych

\begin{tabular}{|l|c|c|}
\hline Scenariusz & $\begin{array}{c}\text { Wartość NPV } \\
\text { w tys. PLN }\end{array}$ & IRR w \% \\
\hline $\begin{array}{l}\text { Optymistyczny, w przypadku zawarcia prognozowanych umów } \\
\text { najmu }\end{array}$ & 59017,30 & 34,15 \\
\hline Bazowy dla zawartych umów najmu & 36955,78 & 26,12 \\
\hline Umiarkowanie pesymistyczny, przy zmniejszeniu wpływów o 20\% & 23477,09 & 19,06 \\
\hline Pesymistyczny, przy zmniejszeniu wpływów o 30\% & 7461,00 & 12,90 \\
\hline
\end{tabular}

Źródło: Opracowanie własne. 


\section{Zmiana wpływów spowodowana wzrostem nakładów inwestycyjnych}

\section{Tabela 3}

Zestawienie uzyskanych wyników wskaźników efektywności NPV i IRR dla trzech scenariuszy rynkowych

\begin{tabular}{|l|c|c|}
\hline Scenariusz & $\begin{array}{c}\text { Wartość NPV } \\
\text { W tys. PLN }\end{array}$ & . IRR w \% \\
\hline $\begin{array}{l}\text { Bazowy dla nakładów przewidzianych w analizie } \\
\text { finansowej i kosztorysach }\end{array}$ & 36955,78 & 26,12 \\
\hline $\begin{array}{l}\text { Umiarkowanie pesymistyczny, przy wzroście nakła- } \\
\text { dów inwestycyjnych o 20\% }\end{array}$ & 23477,09 & 19,06 \\
\hline $\begin{array}{l}\text { Pesymistyczny, przy wzroście nakładów inwestycyj- } \\
\text { nych o 50\% }\end{array}$ & 13259,15 & 10,70 \\
\hline
\end{tabular}

Źródło: Opracowanie własne.

Rysunek 3 przedstawia wrażliwość wewnętrznej stopy zwrotu IRR na procentowe zmiany prognozowanych wpływów związane $z$ ryzykiem nieuzyskania oczekiwanego dochodu z tytułu najmu oraz wrażliwość IRR na wzrost początkowych nakładów inwestycyjnych. Obie linie charakteryzują się stosunkowo dużym nachyleniem do osi $x$, co świadczy o znaczącej wrażliwości projektu inwestycyjnego na wyróżnione parametry rynkowe. Krzywa obrazująca zmiany IRR w zależności od wpływów uzyskanych z najmu powierzchni biurowych scharakteryzowana jest nieco większym kątem nachylenia, można jednak uznać, że w obu analizowanych przypadkach wrażliwość projektu jest średnia. Dane zawarte w tabelach 2 i 3 wskazuja ponadto, że w każdym z analizowanych scenariuszy, od optymistycznego do pesymistycznego, w obu wariantach analizy wrażliwości przedmiotowy projekt cechują wartości wskaźników efektywności przemawiające za przyjęciem proponowanego przedsięwzięcia.

\section{Analiza wraźliwości projektu}

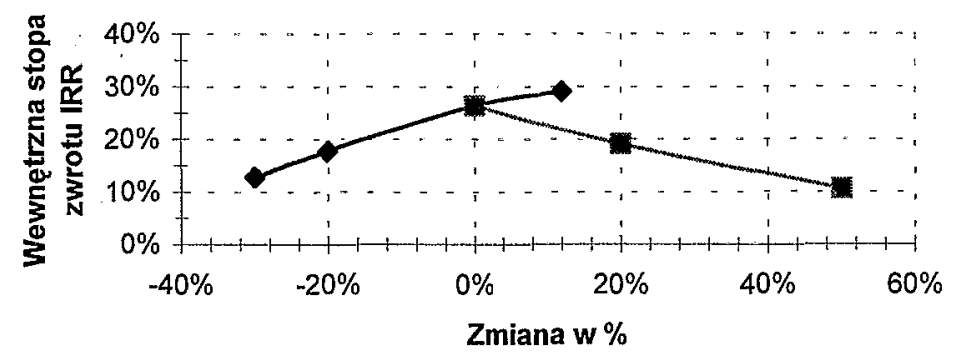

-Zmiana wielkości wpływów -Zmiana nakładów początkowych

\section{Rysunek 3}

Wrażliwość wewnętrznej stopy zwrotu IRR na wyróżnione czynniki ryzyka Źródło: Opracowanie własne. 


\section{Zmienność i okres przetrzymania dla projektu inwestycyjnego}

Wprowadzenie modelu VaR do określania skwantyfikowanego ryzyka projektu inwestycyjnego wymaga zastosowania miarodajnego modelu zachowania się zmienności. Właściwy wybór tego parametru jest jednym z najważniejszych czynników określających efektywność VaR, gdyż obliczenia VaR dla pojedynczego instrumentu w ujęciu ogólnym sprowadzają się do przemnożenia jego zmienności przez wartość pozycji. W istocie obliczanie VaR polega na oszacowaniu maksymalnego ujemnego zwrotu (straty) na portfelu przy danym stopniu ufności i zmienności opartej na jednym odchyleniu standardowym, co pozwala na stwierdzenie, że $95 \%$ zwrotów będzie mniejsze niż 1,645 pomnożone przez zmienność zwrotów. Jednocześnie podkreślenia wymaga fakt, że przez pojęcie zmienności rozumie się zmienność zwrotów lub procentowych zmian cen, a nie zmienność cen aktywów. Rozważając przedmiotowy projekt inwestycyjny pod kątem zmienności rozumianej jako zmienność zwrotów z aktywów, wydaje się, że oparcie obliczeń VaR na poszukiwanym parametrze wynikowym - NPV oraz mierze jego zmienności w postaci współczynnika zmienności odniesionego do jednego odchylenia standardowego i wartości oczekiwanej może być uzasadnione i wiarygodne. Określany współczynnik zmienności dla warunków „brzegowych”, wynikających z analizy scenariuszy, pokazuje maksymalny zakres potencjalnych strat wynikających z zainwestowania kapitału $\mathrm{w}$ dane przedsięwzięcie. VaR natomiast, liczone dla wskaźnika efektywności NPV, jest informacja, że z prawdopodobieństwem równym zadanemu poziomowi ufności można stwierdzić, iż obliczona wartość NPV nie będzie niższa niż określona modelem Value at Risk.

Istnieją więc dwa etapy zabezpieczenia inwestora przed ryzykiem: oparty na analizie wrażliwości, opisujący potencjalne straty (ryzyko) w sposób „,bezpośredni”, oraz bazujący na podstawowych ocenach ryzyka i wykorzystujący określone w nich parametry na potrzeby analizy danych wyjściowych wskaźników efektywności będących kryteriami podejmowanych decyzji. W rozważanym przypadku takim parametrem łączącym oba etapy analizy ryzyka jest współczynnik zmienności, który dla przedmiotowego projektu wynosi:

- dla wrażliwości względem współczynnika wykorzystania powierzchni biurowych:

$$
W_{z m}=\frac{17783,606}{35274,435}=0,504,
$$

- dla wrażliwości względem zmiany nakładów inwestycyjnych: 


$$
W_{z m}=\frac{16708,098}{31982,549}=0,522
$$

Drugim podstawowym parametrem łączącym oba etapy analizy ryzyka jest okres prognozy projektu, identyfikowany w modelu VaR jako okres przetrzymania. W zależności od rodzaju analizowanych aktywów okres przetrzymania może być inaczej postrzegany przez inwestora. W przypadku płynnych aktywów znajdujących się w portfelu inwestora uzasadniony jest wybór jednodniowego okresu przetrzymania, ale wówczas nie uwzględnia się czasu wyprzedaży pozycji niepłynnych lub dużych pozycji, przetrzymywanych np. przez banki. Innym sposobem definiowania okresu przetrzymania jest czas niezbędny do zabezpieczenia inwestora przed ryzykiem rynkowym. Według jeszcze innych poglądów, okres przetrzymania to czas, w którym skład portfela pozostaje praktycznie niezmieniony. Pomijając zjawiska wtórne występujące wraz ze zwiększaniem okresu przetrzymania, takie jak ,powrót do średniej”, w obliczeniach wartości narażonej na ryzyko stosowanej dla długoterminowych projektów inwestycyjnych okres przetrzymania należałoby identyfikować $z$ okresem szczegółowej prognozy, najczęściej obejmującej okres spłaty kredytu. Ryzyko nieuzyskania określonych parametrów efektywności przedsięwzięcia $\mathrm{w}$ tak scharakteryzowanym okresie jest informacją najbardziej pożądaną, głównie przez kredytodawcę, ale również nie bez znaczenia dla kredytobiorcy. Dla obu czynników - zmienności i okresu przetrzymania - wymagane jest przede wszystkim zachowanie zasady współmierności.

W obliczeniach VaR dla analizowanego projektu zarówno zmienność, jak i okres przetrzymania zostały odniesione do 11-letniej szczegółowej prognozy strumieni pieniężnych obejmującej okres spłaty kredytu.

\section{Skwantyfikowane ryzyko - VaR dla przedsięwzięcia inwestycyjnego}

\section{Zastosowanie metody kowariancji}

Metoda kowariancji stosowana do szacowania VaR jest wprawdzie modelem statystycznym, ale analityczny sposób jej obliczania pozwala, po dokonaniu niezbędnych analiz, na szybkie i stosunkowo proste określenie wartości narażonej na ryzyko. Przeprowadzony na potrzeby adaptacji modelu VaR i zastosowania metody kowariancji proces analizy rynkowej $i$ finansowej pozwolił na dokonanie następujących kalkulacji: 
- wartości VaR metodą kowariancji dla pojedynczego instrumentu NPV i rynkowego czynnika ryzyka związanego z nieuzyskaniem spodziewanych wpływów $\mathrm{z}$ wynajmu powierzchni biurowych:

$$
\begin{aligned}
& V a R=1,65 \times W_{z m} \times N P V_{B A Z O W E}=1,65 \times 0,504 \times 37957,77=31575,07 \\
& \text { tys. } P L N,
\end{aligned}
$$

- wartości VaR metodą kowariancji dla pojedynczego instrumentu NPV i ryzyka związanego ze żwiększeniem nakładów inwestycyjnych: .

$$
\begin{aligned}
& V a R=1,65 \times W_{z m} \times N P V_{B A Z O W E}=1,65 \times 0,522 \times 37957,77=32718,89 \\
& \text { tys. PLN. }
\end{aligned}
$$

Interpretując uzyskane wyniki zgodnie $\mathrm{z}$ istotą metody kowariancji, można powiedzieć, że z 95-procentową pewnością w ciagu okresu analizy, obejmującego okres spłaty kredytu, zmniejszenie obliczanego NPV będące następstwem zidentyfikowanych rynkowych czynników ryzyka nie przekroczy odpowiednio wartości 31 575,07 tys. PLN i 32 718,89 tys. PLN. Można też zaryzykować stwierdzenie, że w przypadku odstapienia od bieżącego monitoringu rzeczywistych wpływów osiaganych $\mathrm{z}$ nieruchomości i okresie prognozy oraz niekorzystnych zmian parametrów wyjściowych przyjętych do obliczeń istnieje 95-procentowe prawdopodobieństwo, że wskaźnik efektywności projektu inwestycyjnego NPV nie osiągnie wartości ujemnej. Inwestycja będzie więc wciąż opłacalna, gdyż maksymalna „strata” NPV w okresie prognozy nie przekroczy 31575,07 tys. lub 32718,89 tys. przy wartości bazowej na poziomie 37957,77 tys.

\section{Podsumowanie i wnioski}

Value at Risk - powstała przed kilkunastoma laty metoda mierząca potencjalną stratę na portfelu, przy z góry ustalonym prawdopodobieństwie trafności prognozy - podlega ciagłemu doskonaleniu znajdując coraz szersze zastosowanie w pracach instytucji rynku finansowego. Zarządzanie portfelem inwestycyjnym tych podmiotów nieodłącznie wiąże się z zarządzaniem ryzykiem procesem wspomaganym współcześnie modelami ryzyka. Wydaje się jednak, że w sytuacji malejącej rentowności sektora bankowego proces zarządzania ryzykiem powinien być również uwzględniany po stronie działalności operacyjnej, głównie kredytowej. Istnieje więc potrzeba budowania modeli ryzyka kredytowego, obejmującego nie tylko analizę potencjalnego kredytobiorcy, ale również ryzyka związanego $\mathrm{z}$ poziomem zabezpieczenia wierzytelności w okresie spłaty kredytu. Prezentowana w pracy próba wdrożenia wyspecjali- 
zowanego, na potrzeby rynku kapitałowego, narzędzia pomiaru skwantyfikowanego ryzyka do analizy ryzyka wyłącznego inwestycji na rynku nieruchomości dostarcza następujących spostrzeżeń:

1. W sytuacji znaczącego wzrostu inwestycji na rynku nieruchomości, finansowanych głównie poprzez instytucje bankowe, istnieje konieczność opracowania modeli ryzyka opisujących zachowania tego segmentu rynku i pozwalających na ograniczenie ewentualnych strat, będacych następstwem nadmiernie optymistycznych ocen i błędnych rachunków efektywności inwestycji.

2. Znane i wykorzystywane na rynku kapitałowym modele ryzyka stanowią bogaty materiał pozwalający na powiązanie obu segmentów rynku - kapitałowego i rzeczowego - oraz empiryczną weryfikację, obejmującą również projekty inwestycyjne.

3. Model VaR może być wykorzystany do określania skwantyfikowanego ryzyka wyłącznego projektu inwestycyjnego scharakteryzowanego wskaźnikiem opłacalności NPV, ale uzyskane wyniki należy traktować z ograniczonym zaufaniem.

\section{Literatura}

BEST P., Wartość narażona na ryzyko. Dom Wydawniczy ABC, Kraków 2000.

BRIGHAM E.F., GAPENSKI L.C., Zarzqdzanie finansami. Polskie Wydawnictwo Ekonomiczne, Warszawa.

JAJUGA K., JAJUGA T., Inwestycje. Wydawnictwo Naukowe PWN, Warszawa 2002.

ROGOWSKI W., KALKOL M., Zarzqdzanie ryzykiem banku przy inwestycjach mieszkaniowych z uwzglednieniem wpływu ryzyka kredytowego nabywców mieszkań. Uwarunkowania i kierunki rozwoju modelowania ryzyka kredytowego wierzytelności hipotecznych. Związek Banków Polskich. Warszawa 2003.

JAJUGA K., CEGIELSKI K., Nieruchomości nr 11. C.H. Beck, Listopad 2003.

JONES LANG LASALLE, Rynek nieruchomości w Warszawie. Wrzesień 2003.

\section{Application of Covariance Method for Risk Assessing on the Commercial Real Estate Market}

\section{Abstract}

The Value at Risk model allows answering the basic question asked by investor. How much money could be lost with given financial resources involved into given project, in fixed time and fixed risk preference? 
The covariance method used to estimate VaR is static model, but analytic manner of computing allows, after essential analysis, to determine value at risk relatively clearly and quickly.

Presented attempt of initiating tool to analyzing quantified risk of investment on real estate market, specialized for capital market, gives observations:

a) in the situation of significant growth of investments on real estate market, financed mainly by banking institutions, there is necessity to work out risk models for this market segment, allowing to limit excessive losses caused by too optimistic prices and inappropriate calculations of the effectiveness of the investment,

b) well known and used risk models for capital market are basics for connection the both market segments - capital and real - and empirical verification, including investing projects,

c) VaR model can be used for determining quantified risk of an investing project, characterized by profitability ratio Net Present Value, but received results should be treated with limited confidence. 


\section{Załączniki}

Wariant bazowy

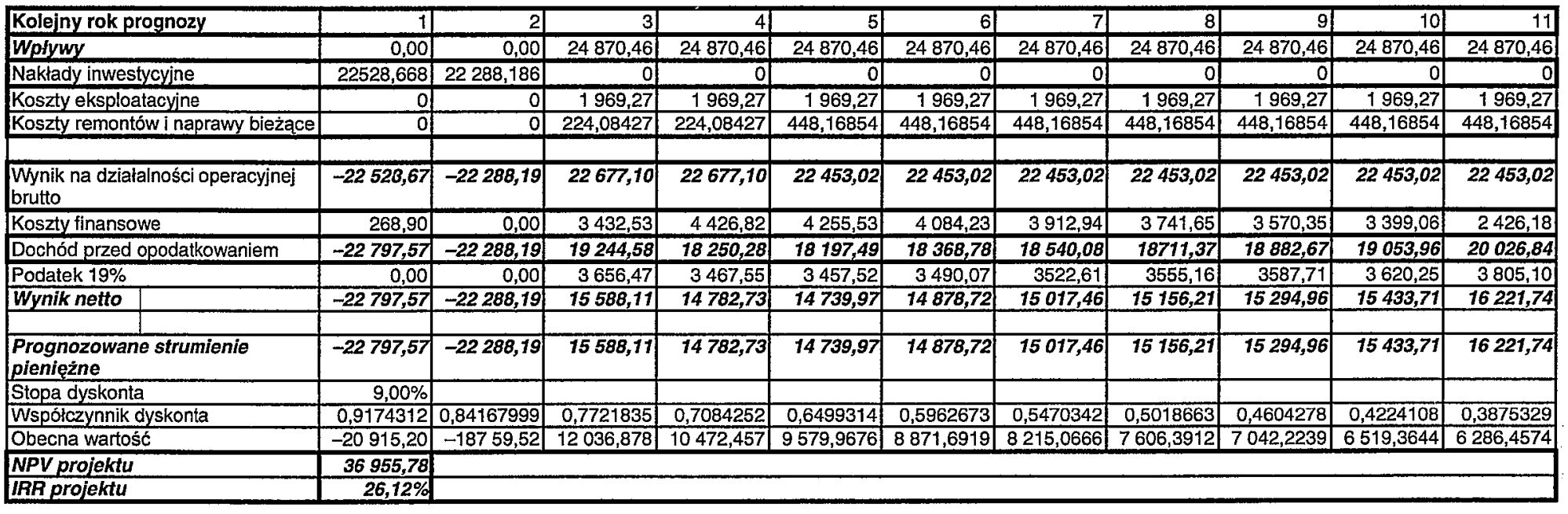

Źródło: Opracowanie własne. 
Wariant umiarkowanie pesymistyczny

\begin{tabular}{|c|c|c|c|c|c|c|c|c|c|c|c|}
\hline Nakłady inwestycyjne & 27034,402 & 26745,823 & 0 & 0 & 0 & 0 & 0 & 0 & 0 & 0] & 0 \\
\hline Koszty eksploatacyine & $\overline{0}$ & of & 1984,24 & 1984,24 & 1984,24 & 1984,24 & 1984,24 & 1984,24 & 1984,24 & 1984,24 & 1984,24 \\
\hline Koszty remontów i naprawy bieżące & 0 & 0 & 268,9011 & 268,9011 & 537,8022 & 537,8022 & 537,8022 & 537,8022 & 537,8022 & 537,8022 & 537,8022 \\
\hline $\begin{array}{l}\text { Wynik na dziakalności operacyjnej } \\
\text { brutto }\end{array}$ & $-27034,40$ & $-26745,82$ & 22617,32 & 22617,32 & 22348,42 & 22348,42 & 22348,42 & 22348,42 & 22348,42 & 22348,42 & 22348,42 \\
\hline Koszty finansowe & 358,53 & 0,00 & 4576,72 & 5902,45 & 5674,06 & 5445,67 & 5217,27 & 4988,88 & 4760,49 & 4532,10 & 3234,92 \\
\hline Dochód przed opodatkowaniem & $-27392,94$ & $-26745,82$ & 18040,60 & 16714,87 & 16674,36 & 16902,76 & 17131,15 & 17359,54 & 17587,93 & 17816,33 & 19113,51 \\
\hline Podatek $19 \%$ & 0,00 & 0,00 & 3427,71 & 3175,83 & 3168,13 & 3211,52 & 3254,92 & 3298,31 & 3341,71 & 3385,10 & 3631,57 \\
\hline Wynik netto & $-27592,94$ & 26745,82 & 14612,89 & 13539,05 & 13506,23 & 13691,23 & 13876,23 & 14061,23 & 14246,23 & 14431,22 & 15481,94 \\
\hline \multirow{2}{*}{$\begin{array}{l}\text { Prognozowane strumienie } \\
\text { pienieżne }\end{array}$} & $-27392,94$ & 26745,82 & 14612,89 & 13539,05 & 13506,23 & 13691,23 & 13876,23 & $14061,23 \#$ & 14246,23 & 14431,22 & 15481,94 \\
\hline & & & & & & & & & & & \\
\hline Stopa dyskonta & $9,00 \%$ & & & & & & & & & & \\
\hline Współczynnik dyskonta & 0,9174312 & 0,84168 & 0,772183 & 0,708425 & 0,649931 & 0,596267 & 0,547034 & 0,501866 & 0,460428 & 0,422411 & 0,387533 \\
\hline Obecna wartość & $-25131,13$ & $-22511,424$ & 11283,83 & 9591,402 & 8778,126 & $8,163,635$ & 7590,773 & 7056,856 & 6559,358 & 6095,905 & 5999,76 \\
\hline NPV projektu & 23477,09 & & & & & & & & & & \\
\hline IRR projektu & $19,06 \%$ & & & & & & & & & & \\
\hline
\end{tabular}

Źródło: Opracowanie własne. 
Wariant zmiany nakładów i wpływów

\begin{tabular}{|c|c|c|c|c|c|c|c|c|c|c|c|}
\hline & 2004 & 2005 & 2006 & 2007 & 2008 & 2009 & 2010 & 2011 & 2012 & 2013 & 2014 \\
\hline Kolejny rok prognozy & 1 & $\overline{2}$ & $\overline{3}$ & 4 & 5 & 6 & $\overline{7}$ & 8 & g & 10 & 11 \\
\hline Wpływy & 0,00 & 0,00 & 24870,46 & 27180,80 & 27180,80 & 27180,80 & 27180,80 & 27180,80 & 27180,80 & 27180,80 & 27180,80 \\
\hline Nakłady inwestycyjne & 22528,668 & 22288,186 & $\overline{0}$ & 0 & 0 & 0 & $\overline{0}$ & $\overline{0}$ & 의 & 0) & 0 \\
\hline Koszty eksploatacyine & 0 & $\underline{0}$ & 1969,27 & 1969,27 & 1969,27 & 1969,27 & 1969,27 & 1969,27 & 1969,27 & 1969,27 & 7969,27 \\
\hline Koszty remontów i naprawy bieżace & 0 & $\overline{0}$ & 224,0843 & 224,0843 & 448,1685 & 448,1685 & 448,1685 & 448,1685 & 448,1685 & 448,1685 & 448,1685 \\
\hline $\begin{array}{l}\text { Wynik na działalności operacyjnej } \\
\text { brutto }\end{array}$ & $-22528,67$ & $-22288,19$ & 22677,10 & 24987,44 & 24763,35 & 24763,35 & 24763,35 & 24763,35 & 24763,35 & 24763,35 & 24763,35 \\
\hline Koszty finansowe & 268,90 & 0,00 & 3432,53 & 4426,82 & 4255,53 & 4084,23 & 3912,94 & 3741,65 & 3570,35 & 3399,06 & 2426,18 \\
\hline Dochód przed opodatkowaniem & $-22797,57$ & $-22288,19$ & 19244,58 & 20560,62 & 20507,83 & 20679,12 & 20850,41 & 21021,71 & 21193,00 & 21364,29 & 22337,18 \\
\hline Podatek 19\% & 0,00 & 0,00 & 3656,47 & 3906,52 & 3896,49 & 3929,03 & 3961,58 & 3994,12 & 4026,67 & 4059,22 & 4244,06 \\
\hline Wynik netto & \begin{tabular}{|l|}
$-22797,57$ \\
\end{tabular} & $-22288,19$ & 15588,11 & 16654,10 & 16611,34 & 76750,09 & 16888,83 & 17027,58 & 17166,33 & 17305,08 & 18093,17 \\
\hline $\begin{array}{l}\begin{array}{l}\text { Prognozowane strumienie } \\
\text { pieniężne }\end{array} \\
\end{array}$ & $-22797,57$ & $-22288,19$ & 15588,11 & 16654,10 & 16611,34 & 16750,09 & 16888,83 & 17027,58 & 17166,33 & 17305,08 & 18093,11 \\
\hline Stopa d & $9,00 \%$ & & & & & & & & & & \\
\hline ik dyskonta & 0,9174312 & 0,84168 & 0,772183 & 0,708425 & 0,649931 & 0,596267 & 0,547034 & 0,501866 & 0,460428 & 0,422411 & 0,387533 \\
\hline Obecna wartość & $-20915,20$ & $-18759,52$ & 12036,88 & 11798,18 & 10796,23 & 9987,53 & 9238,771 & 8545,57 & 7903,855 & 7309,852 & 7011,675 \\
\hline NPV projektu & 44953,83 & & & & & & & & & & \\
\hline IRR projektu & $1,12 \%$ & & & & & & & & & & \\
\hline
\end{tabular}

Źródło: Opracowanie własne. 
Warianty optymistyczne

\begin{tabular}{|c|c|c|c|c|c|c|c|c|c|c|c|}
\hline Kolejny rok prognozy & 1 & 2 & 3 & 4 & 5 & 6 & 7 & 8 & 9 & 10 & 11 \\
\hline Wplywy & $\overline{0,00}$ & 0,00 & 27977,67 & 30681,81 & 30681,81 & 30681,81 & 30681,81 & 30681,81 & 30681,81 & 30681,81 & 30681,81 \\
\hline Nakłady inwestycyjne & 22528,668 & 22288,186 & $\overline{0}$ & 0 & 0 & 0 & 0 & $\overline{0}$ & 0 & 의 & 0 \\
\hline Koszty eksploatacyine & $\overline{0}$ & 0 & 1969,274 & 1969,274 & $+969,274$ & 1969,274 & 1969,274 & 1969,274 & 1969,274 & 1969,274 & 1969,274 \\
\hline Koszty remontów i naprawy bieżące & $\overline{0}$ & 0 & 224,0843 & 224,0843 & 448,1685 & 448,1685 & 448,1685 & 448,1685 & 448,1685 & 448,1685 & 448,1685 \\
\hline $\begin{array}{l}\text { Wynik na działalności operacyjnej } \\
\text { brutto }\end{array}$ & $-22528,67$ & $-22288,19$ & 25784,31 & 28488,45 & 28264,37 & 28264,37 & 28264,37 & 28264,37 & 28264,37 & 28264,37 & 28264,37 \\
\hline Koszty finansowe & 268,90 & 0,00 & 3432,53 & 4426,82 & 4255,53 & 4084,23 & 3912,94 & 3741,65 & 3570,35 & 3399,06 & 2426,18 \\
\hline Dochód przed opodatkowaniem & $-22797,57$ & $-22288,19$ & 22351,79 & 24061,63 & 24008,84 & 24180,14 & 24351,43 & 24522,72 & 24694,02 & 24865,31 & 25838,19 \\
\hline Podatek $19 \%$ & 0,00 & 0,00 & 4246,84 & 4571,71 & 4561,68 & 4594,23 & 4626,77 & 4659,32 & 4691,86 & 4724,41 & 4909,26 \\
\hline Wynik netto & $-22797,57$ & $-22288,19$ & 18104,95 & 19489,92 & 19447,16 & 19585,91 & 19724,66 & 19863,41 & 20002,15 & 20140,90 & 20928,94 \\
\hline $\begin{array}{l}\text { Prognozowane strumienie } \\
\text { pienieżne }\end{array}$ & $-22797,57$ & $-22288,19$ & 18104,95 & 19489,92 & 19447,16 & 19585,91 & 19724,66 & 19863,41 & 20002,15 & 20140,90 & 20928,94 \\
\hline Stopa dyskonta & $9,00 \%$ & & & & & & & & & & \\
\hline Wspólczynnik dyskonta & 0,9174312 & 0,84168 & 0,772183 & 0,708425 & 0,649931 & 0,596267 & 0,547034 & 0,501866 & 0,460428 & 0,422411 & 0,387533 \\
\hline Obecna wartość & $-20915,20$ & $-18759,52$ & 13980,34 & 13807,15 & 12639,32 & 11678,44 & 10790,06 & 9968,774 & 9209,547 & 8507,735 & 8110,65 \\
\hline NPV projektu & 59017,30 & & & & & & & & & & \\
\hline IRR projektu & $34,75 \%$ & & & & & & & & & & \\
\hline
\end{tabular}

Źródło: Opracowanie własne. 
Wariant pesymistyczny

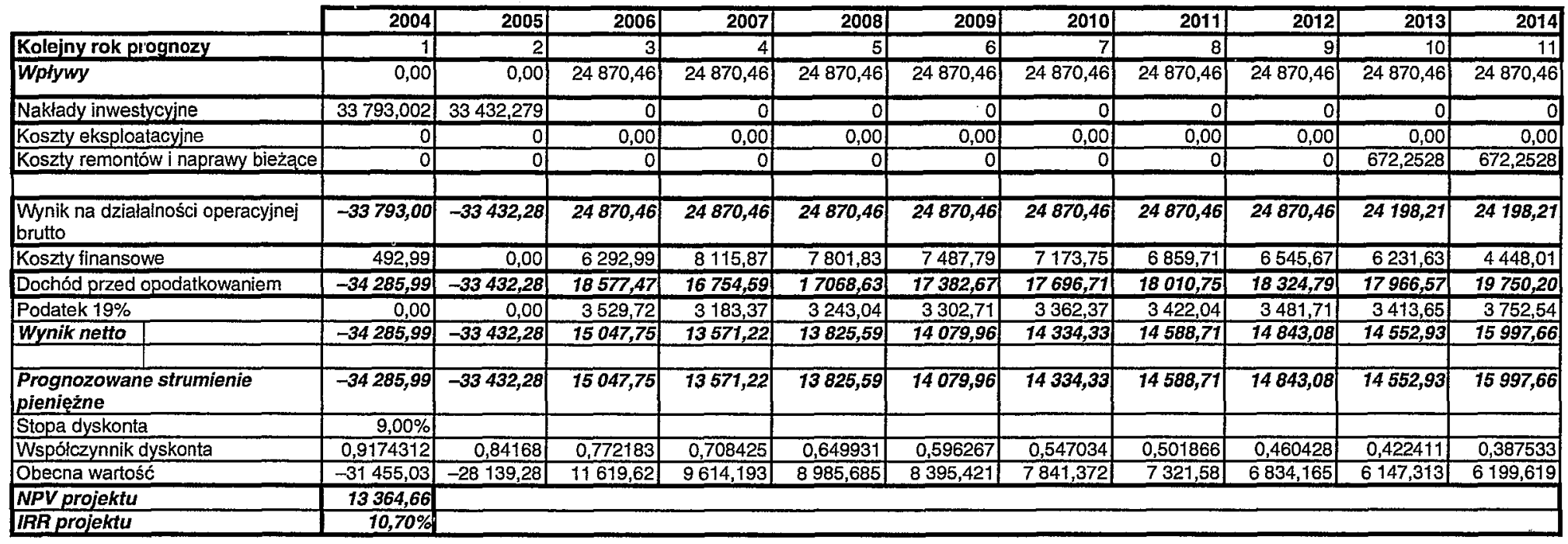

Źródło: Opracowanie własne. 